\title{
Public Space Sharing Strategies for Youth Education Building
}

\author{
Misheng Lin $^{1, *}$, and Yang Wang ${ }^{1,2}$ \\ ${ }^{1}$ School of Architecture, South China University of Technology, 510640 Guangzhou, Guangdong, China \\ ${ }^{2}$ South China University of Technology Architectural Design and Research Institute Co., Ltd, 510640 Guangzhou, Guangdong, China
}

\begin{abstract}
Education building can be activated by space sharing strategies to satisfy the large demand of outside school education needs. The public space of youth education building has a more flexible social adaptability than the full-time school. Through case collection, data research, statistical analysis methods, design elements of public space of youth education buildings are studied. Based on the consideration of design elements, the spatial layout modes and design strategies are summarized. These results are helpful for the similar space design in outside school education buildings.
\end{abstract}

\section{Introduction}

\subsection{Public space sharing of educational buildings under social needs}

Due to the insufficiency of Chinese per capita distribution of education resources [1], conventional public schools are hard to satisfy modern education. Parents pay lots of attention to the growth of teenagers through outside school education. Sharing economy promotes the sharing of education building's idle spaces, better serving the society. Space sharing usually refers a transaction to have the equal right to use or acquaintance a same place with others [2-3]. A public building must be the core platform as an intermediary for the connection and distribution of education resources. The most basic task of space sharing should be revitalizing idle resources. Considering the safety of students under the unified management of schools, most public full-time education schools are closed management and not open to the public [4-5]. With the emergence of education economy, various education building spaces have expanded their original possibilities [6]. Among various public buildings that can be shared for public education, the youth education building is more flexible and adaptable than the traditional closed-managed school. The youth education building holder provides space as a functional platform. Through the platform, the usage of the space can be negotiated, thus multiple activities can be reasonably arranged.

\subsection{Review of youth education building in China}

In China, a youth refers to a statutory minor who are among 6 to 18 years old. Youth education building, such as the Youth Activity Centre, Youth Science Museum, and Youth Education Base, refers to a type of independent outside school education institute [7]. It provides a systematic, standardized supplementary education activity. Nowadays, the education industry is highly competitive, youth education buildings are constantly increasing their range of openness. In 1949, the completion of the Dalian Youth's Cultural Centre, which was reformed by a private school, marked the birth of China's first professional youth education building prototype [8]. After the education revolution from 1969 to 1979 , outside school education has entered a stage of comprehensive reform [9]. Outside school education buildings for youths are gradually regularized. Since 2000, with the improvement of domestic architectural technology and modern design methodology, the architectural design of the youth education building has shown a diversification in its public and opened characteristics [10]. Up to 2020, youth education buildings have experienced more than 70 years of development. Gradually, youth education building attaches great importance to the role of space sharing design in improving teaching experience. This trend greatly arouses the building resources, benefit the society and increase the extra income of the youth education building.

\section{Design Elements of space sharing}

\subsection{Openness of public space}

The youth education building is a public building that almost all spaces are possible for sharing [11]. However, an excessive openness of space sharing will interfere with the normal operation of the original function of the building. Generally, the public space of a youth education building is suitable for sharing. As shown in

* Corresponding author: 568685279@qq.com 
the Table 1 below, fully open space refers to the space open to the public during its' whole operation period. This type includes spaces like the plaza, open courtyard, open overhead floor, porch and open viewing deck. Usually it is a transitional space between the building and the urban public space. It is a space that citizen can enter for legal activities most of the time. Usually, the sharing of this space is free of charge under official applications. Fully open space breaks through the limitations of time management, thus further enhances the physical accessibility of the public space. Semi-open space can be entered and used reasonably within some certain restrictions. This type is usually half indoor and outdoor, including auxiliary spaces such as public foyer, passage hall, traffic space and commercial space. It provides the public with a place to rest, chat or cross. Specific open space is formed by the building's special interface, streamline or segmentation, which has a character of inner openness. This type includes public laboratories, temporary offices, multimedia conference rooms, etc. These spaces are of control that require maintenance and access management. Such space is only shared for specific usage with applications, or within a specific period of official working time. And not all youth education buildings share this type of space.

Table 1. Openness of public space in youth education building

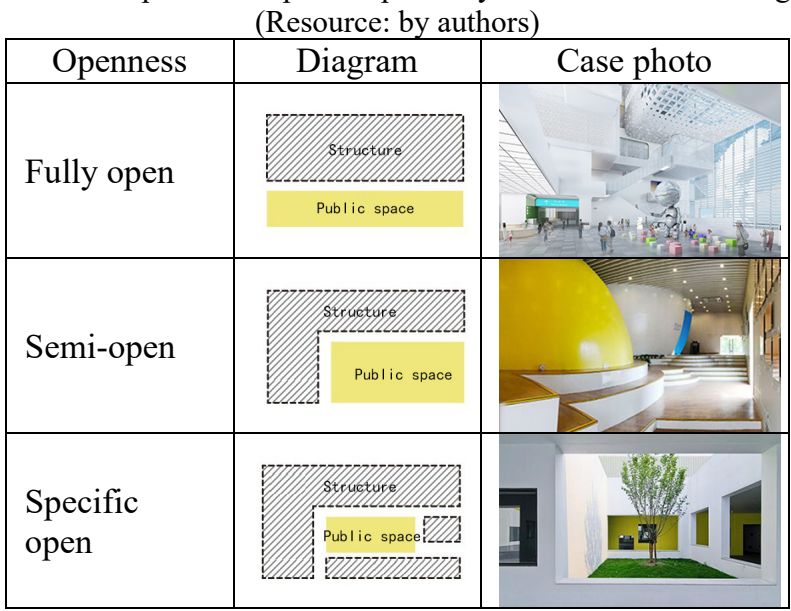

\subsection{Physical and mental needs of youth education}

Youth students are in the transition period from young to mature. They have a strong sense of independence and try to protect their personal privacy. At the same time, they have social curious on the surrounding people. During education, youth students want to be respected and get satisfaction in communication. The youth education building provides a basic study platform for youth students. The building space needs to be accessible and convenient for students. It is necessary to create a comfortable environment which is suitable for the body scale of youth students. Design should be considered from the aspects of space scale, colour, texture to the history, culture, and region of the building. It is necessary to meet the diversity of education functions, provide corresponding places for youth education activities.

\subsection{Specific facility for educational activity}

In order to have an easy sharing access of the public space, safe, practical and durable basic facilities should be provided. Basic infrastructures are necessary for space sharing, such as shading plate and fire protection facilities. Usually, fully open space includes the basic hydropower interface, area delimitation, landmark indication, etc. Semi-open space includes water and electricity pipes, air conditioning, HVAC (Heating Ventilation and Air Conditioning), lighting, intelligent security, self-service machines, etc. Besides, public facilities should create an active atmosphere. A safe and interactive atmosphere can be enhanced according to specific facilities design for youths, teachers and caretakers. Results show that the sharing rate of wellequipped youth education buildings are relatively high.

\subsubsection{Youth body scale furniture}

Many spontaneously education activities need furniture combinations for youth. Furniture inside public space shall be fit for youths' body scale and can be safely assembled for different range of use. For example, combination of body scale seats in the youth education building should meet the requirements of the height and behaviour habit of youths. The weight of seats should not be to light to be thrown, either too heavy to be moved by teenagers.

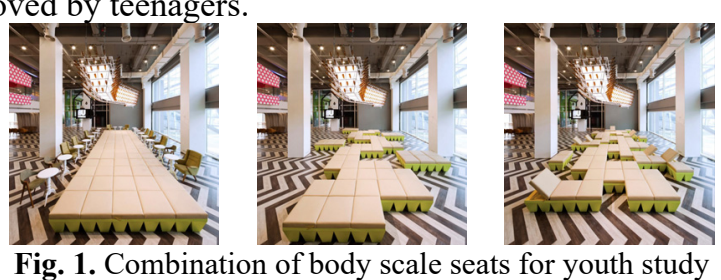

(Sources: archgo.com)

\subsubsection{Safe guard}

Safe guard is an essential complement especial for outside school education security. It is common for the aged to look after the youth in outside school education. Pre-protection and barrier-free design should be considered for public spaces that may prevent users from impacted, dropped or slipped, etc. Due to foreseeability of public space sharing, a reasonable safety reminder for the caretaker is also a kind of strengthening protection design. For example, anti-slip treatment shall be performed on the floor, reflective warning on height difference floor shall be added, and all power sockets shall be covered with a safety cover.


Fig. 2. Safe guard considering youth behaviours (Sources: architecturalrecord.com) 


\subsubsection{Education game facility}

Education games are very suitable for youth teaching. Education game facilities shall be made of non-angular and anti-drop materials. Youths between the ages of 3 to 6 can learn to communicate in the game within protections of their caretakers. Youths among 6 to 10 years old can choose sport activities under monitoring. And youths over 10 years old are allow to choose adventure activities independently according to their own interests.
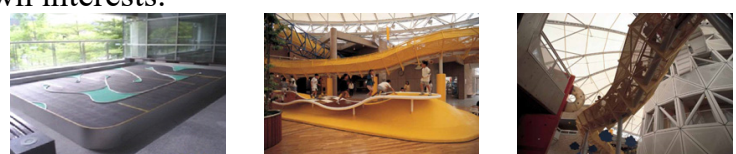

Fig. 3. Educational game facilities in youth education buildings (Sources: by authors)

\section{Design strategies of public space sharing}

\subsection{Layout mode}

The layout mode refers to the coordination of the overall spatial relationship of the public space sharing and building function management. Public space sharing is usually designed clearly so as not to interfere with the original building function. As shown in the following Table 2, the space sharing layout strategy of the youth education building can be divided into 3 modes. It is presumed that the Central has an advantage of centrally management. The obvious division of the public space sharing and the private space management is easier to implement with less interference, which can solve the problem of functional partition. Youth education buildings with complex heights, environments, or rooms tend to use the Multi-Cores. In fact, Multi-Core is more flexible for modern public space sharing. This mode reorganizes the scattered idle space independently and extend them to the society. The Net Format is a kind of spatial pattern with interlacing and fluidity. Youth education building with flat and spacious field is more likely to apply this mode. The public space sharing in this mode is not completely fixed and can be adjusted according to the scale or form of activities.

Table 2. Layout modes of public space sharing (Resource: by authors).

\begin{tabular}{|c|c|c|c|c|}
\hline Mode & Diagram & & Legend & Character \\
\hline \multirow{3}{*}{ Central } & & 0 & $\begin{array}{l}\text { Stable space } \\
\text { sharing }\end{array}$ & \multirow{3}{*}{$\begin{array}{l}\text { The space area } \\
\text { is concentrated } \\
\text { to form one } \\
\text { public sharing } \\
\text { core. }\end{array}$} \\
\hline & & : & $\begin{array}{l}\text { Inner } \\
\text { function }\end{array}$ & \\
\hline & & $\square$ & $\begin{array}{l}\text { Building } \\
\text { range }\end{array}$ & \\
\hline \multirow{3}{*}{$\begin{array}{l}\text { Semi- } \\
\text { Cores }\end{array}$} & & 0 & $\begin{array}{l}\text { Half stable } \\
\text { space } \\
\text { sharing }\end{array}$ & \multirow{3}{*}{$\begin{array}{l}\text { The function } \\
\text { partition is } \\
\text { flexible, which } \\
\text { is convenient } \\
\text { for multiple } \\
\text { activities. }\end{array}$} \\
\hline & & : & $\begin{array}{l}\text { Inner } \\
\text { function }\end{array}$ & \\
\hline & & $\square$ & $\begin{array}{l}\text { Building } \\
\text { range }\end{array}$ & \\
\hline
\end{tabular}

\begin{tabular}{|c|c|c|c|c|}
\hline Mode & Diagram & & Legend & Character \\
\hline \multirow{3}{*}{$\begin{array}{l}\text { Net } \\
\text { Format }\end{array}$} & & ○ & $\begin{array}{l}\text { Potential } \\
\text { space } \\
\text { sharing }\end{array}$ & \multirow{3}{*}{$\begin{array}{l}\text { The free and } \\
\text { versatile } \\
\text { network } \\
\text { organization } \\
\text { provides a } \\
\text { variety of } \\
\text { options. }\end{array}$} \\
\hline & & 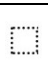 & $\begin{array}{l}\text { Inner } \\
\text { function }\end{array}$ & \\
\hline & & $\square$ & $\begin{array}{l}\text { Building } \\
\text { range }\end{array}$ & \\
\hline
\end{tabular}

\subsection{Space connection}

The connection strategy is to set link of the public space with social needs. For the sake of teaching quality, youth education building generally needs to be regularly managed and maintained. Not all public space of youth education building can be shared to the public. Considering educational requirements, the integrated connection of space can increase the plasticity of the building public space into the urban space system. The space sharing limitation can be compensated through this strategy. Youth education building shall provide a high convenience of participation. This strategy can be achieved by developing an isolated space from the building management system. The isolated space can be enclosed by buildings structures, tall vegetation or guiding structure. As shown in the Table 3, 3 types of connection strategy are listed. It should be noticed that these strategies are side-by-side relationships, thus multiple strategies can be adopted according to actual needs. For example, the Qingpu Youth Activity Center in Shanghai adapts the Virtual space in the entrance. An interior wall void of public opening space has been customized. The wall void encloses an internal virtual space, enhancing the visual enjoyment. The observation from the outside to the inside is relatively weak, which protects the privacy of youth activities. This design allows the public space to be integrated into the multidirectional visual cross network, which ensures the rationality of the internal sharing activities by social environment.

Table 3. Types of connection strategy (Resource: by authors)

\begin{tabular}{|l|l|l|}
\hline Type & Diagram & \begin{tabular}{l} 
Enclosure character \\
\hline $\begin{array}{l}\text { Central } \\
\text { corridor }\end{array}$
\end{tabular} \\
\hline $\begin{array}{l}\text { Inside the building, a } \\
\text { space corridor for } \\
\text { people to walk through } \\
\text { is opened, combined } \\
\text { with the surrounding } \\
\text { urban transportation } \\
\text { network and urban } \\
\text { residents' habits. } \\
\text { court }\end{array}$
\end{tabular}




\begin{tabular}{|c|c|l|}
\hline Type & Diagram & Enclosure character \\
\hline \multirow{5}{*}{$\begin{array}{c}\text { Virtual } \\
\text { space }\end{array}$} & $\begin{array}{l}\text { directly without } \\
\text { passing through the } \\
\text { internal space of the } \\
\text { building. }\end{array}$ \\
\hline & $\begin{array}{l}\text { Baotou Youth } \\
\text { Base }\end{array}$ & $\begin{array}{l}\text { Space with a covered } \\
\text { top is provided at the } \\
\text { edge of the building. } \\
\text { The projection area of } \\
\text { the upper cover is } \\
\text { enclosed to form a } \\
\text { transition space } \\
\text { between the interior } \\
\text { and exterior. }\end{array}$ \\
\hline & $\begin{array}{l}\text { Second Youth } \\
\text { Institute }\end{array}$ & \\
\hline
\end{tabular}

\subsection{Humanity optimization}

The humanity optimization of public space is the promotion content of space sharing. It is an ergonomics of space through certain design principles and methods. The humanization role is to provide users with psychological buffer space in space sharing. As shown in Table 4, there are respective humanity optimization methods for the 5 spatial problems. Combining with these methods, there are 2 strategies that can be used according to the vertical and horizontal space system.

Table 4. Humanity optimization methods of public space sharing problems (Resource: by authors)

\begin{tabular}{|c|c|c|c|}
\hline Problem & $\begin{array}{l}\text { Humanity } \\
\text { diagram }\end{array}$ & $\begin{array}{l}\text { Case } \\
\text { analysis }\end{array}$ & Description \\
\hline $\begin{array}{l}\text { Too } \\
\text { excessive or } \\
\text { too empty. } \\
\text { difficult for } \\
\text { social } \\
\text { activities. }\end{array}$ & •KIND̈o & $\begin{array}{l}\text { Dongguan } \\
\text { Changan } \\
\text { Town Youth } \\
\text { Base }\end{array}$ & $\begin{array}{l}\text { Properly } \\
\text { divide and } \\
\text { enclose } \\
\text { suitable } \\
\text { space for } \\
\text { activities. }\end{array}$ \\
\hline $\begin{array}{l}\text { Too narrow, } \\
\text { crowded, or } \\
\text { even losing } \\
\text { the sense of } \\
\text { distance. }\end{array}$ & & $\begin{array}{l}\text { Guangzhou } \\
\text { Second Youth } \\
\text { Institute }\end{array}$ & $\begin{array}{l}\text { Increase } \\
\text { space sense } \\
\text { by opening } \\
\text { space joint, } \\
\text { borrowing } \\
\text { outdoor } \\
\text { scenes. }\end{array}$ \\
\hline $\begin{array}{l}\text { The channel- } \\
\text { like space is } \\
\text { too short to } \\
\text { provide } \\
\text { communicati } \\
\text { ng space. }\end{array}$ & $\stackrel{\mathrm{FUN}}{\rightarrow}$ & $\begin{array}{l}\text { Jiangmen } \\
\text { Youth } \\
\text { Institute }\end{array}$ & $\begin{array}{l}\text { Increase the } \\
\text { feasibility of } \\
\text { the channel } \\
\text { by adding } \\
\text { interior } \\
\text { landscapes } \\
\text { or joints. }\end{array}$ \\
\hline $\begin{array}{l}\text { Distance } \\
\text { between } \\
\text { passages is } \\
\text { too long, not } \\
\text { conducive. }\end{array}$ & 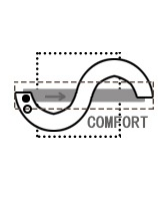 & $\begin{array}{l}\text { Dongguan } \\
\text { Changan } \\
\text { Town Youth } \\
\text { Base }\end{array}$ & $\begin{array}{l}\text { Partial } \\
\text { design } \\
\text { convenient } \\
\text { access for } \\
\text { direct path. }\end{array}$ \\
\hline
\end{tabular}

\begin{tabular}{|l|l|l|l|}
\hline Problem & $\begin{array}{l}\text { Humanity } \\
\text { diagram }\end{array}$ & $\begin{array}{l}\text { Case } \\
\text { analysis }\end{array}$ & Description \\
\hline $\begin{array}{l}\text { The division } \\
\text { of }\end{array}$ & $\begin{array}{l}\text { intersections, } \\
\text { ramps, and } \\
\text { trails are too } \\
\text { fragmented }\end{array}$ & $\begin{array}{l}\text { Enhancing } \\
\text { the guiding } \\
\text { and direct } \\
\text { system } \\
\text { through key } \\
\text { nodes. }\end{array}$ \\
\hline
\end{tabular}

\subsubsection{Communication joint}

When the range of public space provided by the youth education building is not reasonably to be shared, a communication joint with proper dimensions can be appropriately implanted to refine this situation. If the joint is placed in the middle of the space, the whole space shall be relatively separated into several smaller zone. Activities nearby the zone have less interference with the other functions of the original space. Else if the joint is placed at the edge or corner, it helps to create a visible spatial zone. When a user passes, it is possible to recognize this special zone. And this joint can be designed to activate the atmosphere in combination with specific facilities. For example, Guangzhou Second Youth Institute combines some colourful corners to enlarge the corner space for the youths. There are rest seats with some game facilities placed in the corner of the rest zone. Natural skylight adapted to subtropical climate is adopted at the top of this space, which can introduce air and natural light. Joints create a sense of comfort in the visual experience for young people.

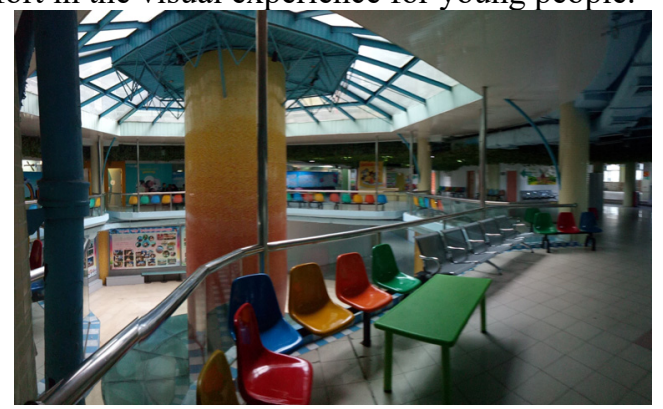

Fig. 4. Corner communication joint in Guangzhou Second Youth Institute (Sources: by authors)

\subsubsection{Vertical segmentation}

Vertical segmentation is an intuitive design strategy for human visual perception. The ascending or sinking of the floor interface can divide the spatial content by enriching the level of space through the micro-height difference. The vertical space is effectively separated to meet the temporary private scope during sharing. And under the premise of satisfying the use of the layer height, a stage, platform or a mezzanine can be added to divide the part of the space into several levels. When adding the sharing area of the original space in the same area, the space can be more useful. For example, in the Qinghai youth education centre in Guangzhou, an performance stage is set to define different heights in the vertical direction of the atrium. Spaces with different 
heights are distinguished by contrasting the colour and material of the paving. The slightly higher space highlights the stage as a designated activity area for youths, creating a strong sense of exclusive communication space for them.

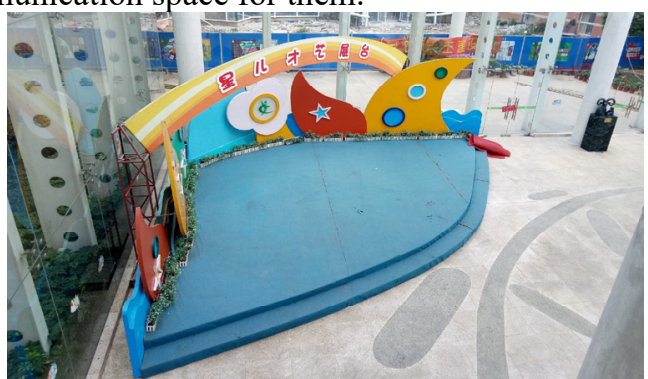

Fig. 5. Vertical segmentation of Qinghai youth education centre in Guangzhou (Sources: by authors)

\section{Conclusion}

As a public welfare institution, the youth education building has gradually gained attention to the social sharing needs of its public space. Results show that at present, most of the space sharing of youth education buildings in China only allows public space to be shared to the public. The internal function space such as classroom, office and multimedia room are still not ready for the sharing mode. However, with the advent of the internet information and the development of mass media, education socialization has become an inevitable trend of education reform. The socialization of educational resources also requires the youth education building to increase its openness to the society. This paper summarizes the elements and design strategies of public space sharing by analysing engineering cases of youth education buildings. Three layout modes are proposed based on the condition of spatial agglomeration and morphological characteristics. The strategies of space connections and humanity optimization are summarized. These strategies may enhance the social education and community service functions of the youth education buildings. The open sharing characteristics of the public space will be further highlighted. Space sharing will not only meet the needs of the original use, but also meet the needs of the public and become a friendly neighbourhood of citizens.

\section{References}

1. C. Heyin, H. Yu, L. Jingwei, and S. Xiaojie, The impact of environmental regulation, shadow economy, and corruption on environmental quality: Theory and empirical evidence from China, Journal of Cleaner Production, Vol. 195 No. 1, pp. 200-214. (2018)

2. J. Hamari, M. Sjöklint, and A. Ukkonen, "The sharing economy: Why people participate in collaborative consumption", Journal of the association for information science and technology, Vol. 67 No. 9, pp. 2047-2059. (2016)
3. H. Heinrichs, "Sharing economy: a potential new pathway to sustainability", GAIA-Ecological Perspectives for Science and Society, Vol. 22 No. 4, pp. 228-231. (2013)

4. W. Dan, W. Jingying, L. Hui, and L. Ling, "School context and instructional capacity: A comparative study of professional learning communities in rural and urban schools in China", International Journal of Educational Development, Vol. 52, pp. 1-9. (2017)

5. R. Morton, "Home education: Constructions of choice", International electronic journal of elementary education, Vol. 3 No. 1, pp. 45-56. (2017)

6. A. Malhotra, and M. Van Alstyne, "The dark side of the sharing economy and how to lighten it", Communications of the ACM, Vol. 57 No. 11, pp. 24-27. (2014)

7. J. Sheldon, A. Arbreton, L. Hopkins, and J. B. Grossman, "Investing in success: Key strategies for building quality in after-school programs", American Journal of Community Psychology, Vol. 45 No. 3-4, pp. 394-404. (2010)

8. W. Ying, and K.H. C. Raymond, "Autonomy and control: The struggle of minban schools in China", International Journal of Educational Development, Vol. 45, pp. 89-97. (2015)

9. L. Yang, Z. Yajun, C. Sitong, Z. Jialin, G. Zongchen and C. Peijie, "Associations between parental support for physical activity and moderate-tovigorous physical activity among Chinese school youths: A cross-sectional study", Journal of Sport and Health Science, Vol. 6 No. 4, pp. 410-415. (2017)

10. W. Xiaogang, and Z. Zhuoni, "Population migration and youths's school enrollments in China, 19902005", Social Science Research, Vol. 53, pp. 177190. (2015)

11. M. A. Holleman, M. J. Sundius, and E. J. Bruns, "Building opportunity: Developing city systems to expand and improve after school programs", American journal of community psychology, Vol. 45 No. 3-4, pp. 405-416. (2010) 